\title{
Factors to Enhance Tourist's Ecotourism Loyalty, an Empirical Study in Viet Nam
}

\section{Sinh Duc Hoang}

Tomas Bata University in Zlin, Faculty of Management and Economics, The Czech Republic, Ho Chi Minh City University of Foreign Languages, Information Technology, Vietnam.

E-mail: dhoang@utb.cz

\section{Zuzana Tučková}

Tomas Bata University in Zlin, Faculty of Management and Economics, The Czech Republic.

E-mail: tuckova@utb.cz

\section{Dinh Tran Ngoc Huy}

MBA, Banking University HCMC, Ho Chi Minh City, Vietnam.

International University of Japan, Niigata, Japan. E-mail: dtnhuy2010@gmail.com

\section{Tien Phat Pham}

Tomas Bata University in Zlin, Faculty of Management and Economics, The Czech Republic, Can Tho University, Vietnam. E-mail: tien@utb.cz

Received May 19, 2021; Accepted August 20, 2021

ISSN: $1735-188 X$

DOI: $10.14704 / W E B / V 18 S I 05 / W E B 18257$

\section{Abstract}

In order to fulfill the gaps in the literature, this research aims to develop and test a model for tourist's ecotourism loyalty and eWOM. This research is different from the previous research since the research model integrates the expectation confirmation theory and the theory of planned behavior. Accordingly, this study contributes to the literature by creating the possibility to explore how tourist's ecotourism loyalty and eWOM are greatly influenced by tourism experience, which aligns with previous research findings. This research will emphasize the tourist's ecotourism satisfaction and personal behavior intentions. Therefore, this study is the first of its kind to the study's theoretical contribution through a model to enhance understanding of tourist's ecotourism loyalty and eWOM in Vietnam.

The research findings tell us that developing entertainment services, fun learning, and emotional experience influenced tourists' ecotourism loyalty and eWOM in Vietnam. The government agencies and ecotourism managers should also emphasize these factors when implementing strategies and policies to enhance ecotourism. 


\section{Keywords}

Ecotourism, Loyalty, Vietnam, Sustainability, Tourism Policy. JEL: L83, Z3, Z32.

\section{Introduction}

Many countries announced recently that the tourism industry is experiencing losses of at least $\$ 16.5$ billion annually (Uğur \& Akbiyık, 2020). The government needs to develop strategies and measures to boost the tourism industry. According to Hieu \& Vu (2019), a hospitable image is crucial for a country to implement successful tourism marketing strategies. Implementation of appropriate marketing, communication, and positive talks often creates a suitable destination image that attracts tourists to a particular country. Besides, advancements in technology make it possible for a country to modify its image destination across different tourist experience phases (Harahap \& Dwita, 2020). After touring a given destination, the place's image may negatively or positively influence tourists, depending on their trip experience. As Humairah et al. (2020) point in their research, the tourist may enhance a negative or neutral pre-trip experience of tourist after visiting that destination. The government agencies need to evaluate what experiences should be provided to improve and achieve a positive image. Accordingly, Setiawan (2018) notes that the government's failure to establish a positive destination image conducive to tourists is likely to be dissatisfied and influence other tourists with word of mouth (WOM). This will negatively influence potential tourist's destination image, thus affecting the tourism sector of the country.

We organize our study with introduction, previous studies, methodology, main results, discussion and conclusion.

\section{Research Goal}

From the argument above, the study's primary goal aims to develop a comprehensive model for investigating the effect of tourist expectation (motivation and eWOM) on ecotourism loyalty.

In Vietnam ecotourism has attracted many tourists, local and international over years. 


\section{Literature Review}

\section{Expectancy Confirmation Theory}

The expectancy confirmation theory focuses on customer satisfaction factors and post-purchase behavior among tourists (Sparks, 2007). It implies that a service consumption process begins with initial service expectations based on customer targets and confidence in the destination management's service capacity. The tourists develop performance perceptions during the consumption period and compare the deliverables with pre-purchase service expectations to confirm the expectations. Eco-tourists expect a natural destination with great ambience and services such as accommodation and food production.

Fu et al. (2018) argued that pre-purchase expectations affect customer satisfaction based on actual performance. Higher performance than customer expectation leads to a positive destination image, while a lower performance indicates a poor destination image. The expectations positively affect consumer's perceptions about service quality; however, tourists with higher expectations get a negative confirmation about the service quality. These expectations create satisfaction directly based on how the destination delivers the expected experience.

Confirmation occurs when the destination offers an actual experience that exceeds the pre-purchase customer expectations. This affirmation indicates that the destination is satisfactory due to contentment with the experience. Contentment about tourist experience leads to positive post-service behavior, while negative tourist experience leads to negative post-service behavior. Therefore, the theory posits that customer satisfaction results from tourist expectations driven by the destination image based on their performance. Therefore, a service that surpasses tourist expectations leverages a positive destination image, leadings to perceptions about a good tourist experience that triggers revisits and recommendations intentions that portray loyalty.

\section{Conceptual Framework}

\section{Ecotourism Loyalty}

For ecotourism, client loyalty can be shown via repeating visits to tourism destinations in the nation (Som \& Badarneh, 2011). 
Tourists considered tourism destinations for their future stops because they show a favorable destination image, help to increase client satisfaction and also give them positive experience when travelling.

\section{Ecotourism Satisfaction}

Ecotourism satisfaction is feeling that recognized by tourists responding to emotion or cognition (Bigné et al., 2014).

In fact, client satisfaction is a kind of positive perception and high pleasure shown thorough their emotional reaction when they travel with experiences of consumption.

\section{Methodology}

\section{Research Objective}

Following are research objectives:

- RO1: To investigate the effects of expectation of tourists on ecotourism loyalty.

- RO2: To explore the role of social influence, prosocial behavior, psychological ownership in showing the relationship between expectation of tourists and ecotourism loyalty.

\section{Method and Data}

\section{Data Collection}

This study initially reviewed the existing literature review related to tourist expectation and ecotourism loyalty. Articles published in journals indexed mainly in Scopus and Web of Science databases are considered. Reading these literature can lead to the identification of the existing and unsolved problems. Moreover, this process gives motivation and objective for research. Review on the relationship between tourist expectation and ecotourism loyalty is presented along with relevant research. Through analysing and the existing literature, the study propose a conceptual model (Figure 2) that combine the factors adapted from expectation confirmation theory and investigate their effect on ecotourism loyalty.

A focus group and the pilot test are carried out to ensure comprehension of all questions by subjects. Initially, the study conducts two focus groups in order to examine the adequacy of the proposed model constructs and the relations among them. This step will 
explore whether important variable or relationships are missing from the model. The respondents are two academics as expert in the field of ecotourism, four tour managers and ten tour guides.

Author also used questionnaires, reviewed by 2 experts, 4 tour managers and 10 tour guides in ecotourism field (in $1^{\text {st }}$ round) and then in $2^{\text {nd }}$ round, we conduct a pilot test of 20-30 tourist.

\section{Research Hypotheses}

Based on the literature review, the hypotheses of this study are as below:

Table 1 Research hypotheses

\begin{tabular}{|c|c|}
\hline H1 & Tourist expectation has relation to destination image (positively) \\
\hline H1a & Motivation has relation to destination image (positively) \\
\hline $\mathrm{H} 1 \mathrm{~b}$ & eWOM has relation to Destination Image (positively) \\
\hline $\mathrm{H} 2$ & Ecotourist experience has relation to destination image (positively) \\
\hline H3 & Destination image has relation to ecotourism satisfaction (positively) \\
\hline $\mathrm{H} 4$ & Destination image has relation to ecotourism loyalty (positively) \\
\hline $\mathrm{H} 5$ & Dcotourism satisfaction has relation to ecotourism loyaty (positively) \\
\hline H6 & Ecotourism satisfaction has relation to eWOM intention (positively) \\
\hline H7 & eWOM intention has relation to Ecotourism loyalty (positively) \\
\hline H8 & $\begin{array}{l}\text { Social influence significantly moderate the relationship between Expectation (motivation } \\
\text { and eWOM) and destination image }\end{array}$ \\
\hline H9 & $\begin{array}{l}\text { Prosocial behavior significantly moderate the relationship between Expection (motivation } \\
\text { and eWOM) and destination image }\end{array}$ \\
\hline H10 & $\begin{array}{l}\text { Psychological ownership significantly moderate the relationship between Expection } \\
\text { (motivation and eWOM) and destination image }\end{array}$ \\
\hline H11 & $\begin{array}{l}\text { Social influence significantly moderate the relationship between destination image and } \\
\text { ecotourism satisfaction }\end{array}$ \\
\hline $\mathrm{H} 12$ & $\begin{array}{l}\text { Prosocial behavior significantly moderate the relationship between destination image and } \\
\text { ecotourism satisfaction }\end{array}$ \\
\hline H13 & $\begin{array}{l}\text { Psychological ownership significantly moderate the relationship between destination image } \\
\text { and ecotourism satisfaction }\end{array}$ \\
\hline
\end{tabular}

\section{Main Findings}

\section{Ecotourism in Vietnam}

Since the creation of the Vietnam government's renovation policy in 1986 (Nguyen, 2020), people have developed market-oriented mechanisms and methods that have since then refreshed the country's economy, and positive energy towards the tourism sector has been nourished. However, the tourism sector has continued to remain a significant 
concern for the government (Tseng et al., 2018). For this reason, the government, through the master plan of tourism development for the period 1995-2010 followed by the government on tourism that came into effect in 1999, has demonstrated the effort of the government of Vietnam to enhance the tourism sector to spearhead economic development while preserving the natural conditions and the natural values to improve tourist destination image for both domestic and international tourist experience (Truong \& Le, 2017).

Vietnam is known as the cradle of about 13,000 flora species and approximately 15,000 fauna species that has proved potential for ecotourism development (Jansen et al., 2015). International tourists are guaranteed hands-on experience by exploring the protected national parks, participating in the traditional cultural rituals and celebrations, or enjoying a fascinating canoe trip down the Mekong River (Festival, 2017). The existence of traditional cultures and the provision of lifestyle experiences for tourists have been given priority in all ecotourist programs in Vietnam. The tourist experience is often enhanced by conducting cultural activities with the host communities' emotional participation how the hosting communities have brought about the improvement of participatory activities for tourists in the country. Nurhidayati (2020) reported that most of the tourist has consistently demonstrated loyalty through spreading positive eWOM about Vietnam tourist destination image.

Ecotourism has developed to a source of educational entertainment for tourist who wants to experience the rich natural resource of Vietnam and develop a better understanding of the cultural relics (Anh et al., 2017). Despite the vast benefits that domestic and internal tourists bring to Vietnam's economy, misusing the natural resources to attract them, such as spontaneous creating of inns, resorts, and other luxuries facilities, may negatively impact the country. With the high number of tourists in the country, the executive boards of ecotourism areas will present challenges. Therefore, the government should develop proper plans and strategies to create equilibrium for both the country and the tourism sector. Queen Sirikit Botanic case should be a waking call for the government. This is Thailand's first botanic garden, founded in 1994 and encompasses a forested area of 2,600 acres (Hawkeswood \& Sommung, 2017). And Hang, T.T.B, Nhung, D.T.H., Huy, D.T.N et al (2020) has stated that Vietnam tourism has both opportunities and risk to manage.

However, ecotourism in Vietnam is currently at an early stage. Also, the development of the covid-19 pandemic has caused several challenges in the country as it is difficult for people in the country to find out a satisfactory compromise existing between preserving the natural environment and exploiting it properly to help boost ecotourism in the country. 
Accordingly, Khanh (2020) notes in their research that if the realization of the short-term economic and cultural advantages is prioritized over conserving natural and biological resources, then the ecotourism process in the country will be affected. For the citizens and the Vietnam government to improve the tourist experience, it is vital to develop a strategic plan and standard measures for developing ecotourism as the fasted growth among the various branches of the tourism industry. Meanwhile, this should be done while maintaining the environmental and cultural values of the country.

\section{Testing Scale's Reliability}

\begin{tabular}{|l|l|}
\hline \multicolumn{2}{|l|}{ Reliability Statistics } \\
\hline Cronbach's Alpha & N of Items \\
\hline .814 & 5 \\
\hline
\end{tabular}

\begin{tabular}{|l|l|l|l|l|}
\hline \multicolumn{5}{|l|}{ Item-Total Statistics } \\
\hline & $\begin{array}{l}\text { Scale Mean if } \\
\text { Item Deleted }\end{array}$ & $\begin{array}{l}\text { Scale Variance if } \\
\text { Item Deleted }\end{array}$ & $\begin{array}{l}\text { Corrected Item-Total } \\
\text { Correlation }\end{array}$ & $\begin{array}{l}\text { Cronbach's Alpha if } \\
\text { Item Deleted }\end{array}$ \\
\hline MO1 & 16.8667 & 7.982 & .691 & .757 \\
\hline MO2 & 17.1000 & 7.748 & .631 & .769 \\
\hline MO3 & 16.9667 & 6.999 & .690 & .749 \\
\hline MO4 & 17.1000 & 7.610 & .623 & .771 \\
\hline MO5 & 17.0333 & 8.447 & .416 & .833 \\
\hline
\end{tabular}

Explanatory Factor Analysis

EFA aims to identify the structure of relationship between variable and respondents. The research use Principle Axis Factoring. Promax rotation is being used for EFA.

\section{Discussion and Conclusion}

\section{Practical Implication}

This research shows developing entertainment services, fun learning, and emotional experience influenced tourists' ecotourism loyalty and eWOM in Vietnam. These results may be of interest to policymakers that intend to improve the destination experience of the tourist. The creation of fun and emotional experience will improve the holistic destination image in an ecotourism context. The government agencies and ecotourism managers should also emphasize these factors when implementing strategies and policies to enhance ecotourism. Firstly, the managers should emphasize the environmental interpretation such as fun entertaining tourist. Secondly, they should develop and implement tourist activities such as jungle trekking and bicycling to improve the destination image. Finally, the destination operators should spark and ensure positive relationships through strategies, for 
example, offering good services and therefore, a favorable green destination image will be kept.

Since tourist's ecotourism loyalty and eWOM are influenced by tourist satisfaction and experience, image, the government agencies and NGOs in Vietnam need to work together to develop ecotourism in the country by improving the tourist destinations.

\section{Limitation of Research}

We can, then, expand our research model for other industries.

\section{Acknowledgement}

Thank you editors, friends and brothers to assist this publication.

The authors would like to thank the Internal Grant Agency of FaME for providing financial support to carry out this research. The funding was extended through UTB No. IGA/FaME/005/2020.

\section{References}

Bigné, J.E., Sánchez, I., Andreu, L., \& Sa, I. (2014). The role of variety seeking in short and long run revisit intentions in holiday destinations. International Journal of Culture, Tourism and Hospitality Research, 3(2), 103-115. https://doi.org/10.1108/17506180910962113

Harahap, M.S., \& Dwita, V. (2020). Effect of EWOM on Revisit Intention: Attitude and Destination Image as Mediation Variables (Study in Pasaman Regency Tourism Destinations), 152, 599-609. https://doi.org/https://doi.org/10.2991/aebmr.k.201126.067

Huy, D.T.N., \& Hang, N.T. (2021). Factors that affect Stock Price and Beta CAPM of Vietnam Banks and Enhancing Management Information System-Case of Asia Commercial Bank. Revista Geintec-gestao Inovacao E Tecnologias, 11(2), 302-308.

Huy, D.T.N., Van, P.N., \& Ha, N.T.T. (2021). Education and computer skill enhancing for Vietnam laborers under industry 4.0 and evfta agreement. Ilkogretim Online, 20(4), 1033-1038.

Hien, D.T., Huy, D.T.N., \& Hoa, N.T. (2021). Ho Chi Minh Viewpoints about Marxism Moral Human Resource for State Management Level in Vietnam. Psychology and Education Journal, 58(5), 2908-2914.

Huy, D.T.N. (2021). Banking sustainability for economic growth and socio-economic development-case in Vietnam. Turkish Journal of Computer and Mathematics Education (TURCOMAT), 12(2), 2544-2553.

Huy, D.T.N., Thach, N.N., Chuyen, B.M., Nhung, P.T.H., Tran, D.T., \& Tran, T.A. (2021). Enhancing risk management culture for sustainable growth of Asia commercial 
bank-ACB in Vietnam under mixed effects of macro factors. Entrepreneurship and Sustainability Issues, 8(3), 291-307.

Hang, T.T.B., Nhung, D.T.H., Hung, N.M., Huy, D.T.N., Dat, P.M. (2020). Where Beta is going-case of Vietnam hotel, airlines and tourism company groups after the low inflation period. Entrepreneurship and Sustainability Issues, 7(3), 2282-2298.

Huy, D.T.N. (2015). The Critical Analysis of Limited South Asian Corporate Governance Standards after Financial Crisis. International Journal for Quality Research, 9(4), 741-764.

Huy, D.T.N. (2012). Estimating Beta of Viet Nam listed construction companies groups during the crisis. Journal of Integration and Development, 15(1), 57-71

Huy, D.T.N., Loan, B.T., \& Anh, P.T. (2020). Impact of selected factors on stock price: a case study of Vietcombank in Vietnam. Entrepreneurship and Sustainability Issues, 7(4), 2715-2730. https://doi.org/10.9770/jesi.2020.7.4(10)

Huy, D.T.N., Dat, P.M., \& Anh, P.T. (2020). Building and econometric model of selected factors' impact on stock price: a case study. Journal of Security and Sustainability Issues, 9(M), 77-93. https://doi.org/10.9770/jssi.2020.9.M(7)

Huy, D.T.N., Nhan, V.K., Bich, N.T.N., Hong, N.T.P., Chung, N.T., \& Huy, P.Q. (2021). Impacts of Internal and External Macroeconomic Factors on Firm Stock Price in an Expansion Econometric model-A Case in Vietnam Real Estate Industry. Data Science for Financial Econometrics-Studies in Computational Intelligence, Springer, 898. http://doi-org-443.webvpn.fjmu.edu.cn/10.1007/978-3-030-48853-6_14

Huy, D.T.N., An, T.T.B., Anh, T.T.K., \& Nhung, P.T.H. (2021). Banking sustainability for economic growth and socio-economic development - case in Vietnam. Turkish Journal of Computer and Mathematics Education, 12(2), 2544-2553.

Huy, D.T.N., An, T.T.B., Anh, T.T.K., \& Nhung, P.T.H. (2021). Banking sustainability for economic growth and socio-economic development - case in Vietnam. Turkish Journal of Computer and Mathematics Education, 12(2), 2544-2553.

Hieu, M.V., \& Vu, M.N. (2019). Strategy development from triangulated viewpoints for a fast-growing destination toward sustainable tourism development - a case of Phu Quoc islands, Vietnam. 117-140. https://doi.org/https://doi.org/10.29036/jots.v10i18.86

Hosany, S., \& Witham, M. (2010). Dimensions of Cruisers' Experiences, Satisfaction, and Intention to Recommend. Journal of Travel Research, 49(3), 351-364.

https://doi.org/10.1177/0047287509346859

Huang, M., Cai, F., Tsang, A.S.L., \& Zhou, N. (2009). Making your online voice loud: the critical role of WOM information. European Journal of Marketing, 45(7), 1277-1297. https://doi.org/10.1108/03090561111137714

Hui, T.K., Wan, D., \& Ho, A. (2007). Tourists' satisfaction, recommendation and revisiting Singapore. Tourism Management, 28(4), 965-975.

https://doi.org/10.1016/j.tourman.2006.08.008

Khuong, M.N., \& Phuong, N.T. (2017). The Effects of Destination Image, Perceived Value, and Service Quality on Tourist Satisfaction and Word-of-Mouth — A Study in Ho Chi Minh City, Vietnam. International Journal of Trade, Economics and Finance, 8(5), 217-224. https://doi.org/10.18178/ijtef.2017.8.5.568 
Lam, T., \& Hsu, C.H. (2006). Predicting behavioral intention of choosing a travel destination. Tourism management, 27(4), 589-599. https://doi.org/10.1016/j.tourman.2005.02.003

Lee, M., Lee, S., \& Koh, Y. (2019). Multisensory experience for enhancing hotel guest experience: Empirical evidence from big data analytics. International Journal of Contemporary Hospitality Management, 31(11), 4313-4337.

https://doi.org/10.1108/IJCHM-03-2018-0263

Lee, S., Jeon, S., \& Kim, D. (2011). The impact of tour quality and tourist satisfaction on tourist loyalty: The case of Chinese tourists in Korea. Tourism Management, 32(5), 1115-1124. https://doi.org/10.1016/j.tourman.2010.09.016

Lee, W.H., \& Moscardo, G. (2005). Understanding the impact of ecotourism resort experiences on tourists' environmental attitudes and behavioural intentions. Journal of sustainable tourism, 13(6), 546-565. https://doi.org/10.1080/09669580508668581

Li, T.T., Liu, F., \& Soutar, G.N. (2021). Experiences, post-trip destination image, satisfaction and loyalty: A study in an ecotourism context. Journal of Destination Marketing \& Management, 19. https://doi.org/10.1016/j.jdmm.2020.100547

Hang, N.T., Huy, D.T.N., Tinh, D.T., \& Huyen, D.T. (2021). Educating Students in History and Geography Subjects through Visiting Historical Sites to Develop Local Economy and Community Tourism Services in Thai Nguyen and Ha Giang Provinces, Vietnam. Revista Geintec-gestao Inovacao E Tecnologias, 11(3), 1-12.

Litvin, S.W., Goldsmith, R.E., \& Pan, B. (2008). Electronic word-of-mouth in hospitality and tourism management. Tourism Management, 29, 458-468. https://doi.org/10.1016/j.tourman.2007.05.011

Lyu, S.O. (2016). Travel selfies on social media as objectified self-presentation. Tourism Management, 54, 185-195. https://doi.org/10.1016/j.tourman.2015.11.001

Macinnis, D.J., \& Price, L.L. (1987). The Role of Imagery in Information Processing: Review and Extensions. Journal of Consumer Research, 13(4), 473-491. https://doi.org/https://doi.org/10.1086/209082

Hang, N.T., \& Huy, D.T.N. (2021). Better Risk Management of Banks and Sustainability-A Case Study in Vietnam. Revista Geintec-gestao Inovacao E Tecnologias, 11(2), 481-490.

Thi Hoa, N., Hang, N.T., Giang, N.T., \& Huy, D.T.N. (2021). Human resource for schools of politics and for international relation during globalization and EVFTA. Ilkogretim Online, 20(4), 2448-2452.

Phuong, N.T.T., Huy, D.T.N., \& Van Tuan, P. (2020). The Evaluation of Impacts of a Seven Factor Model on NVB Stock Price in Commercial Banking Industry in Vietnam-and Roles of Discolosure of Accounting Policy in Risk Management. International Journal of Entrepreneurship, 24(1S), 1-13.

Huong, N., Nhan, B.X., Huy, D.T.N., \& Tu, N.T. (2021). Factors Affecting the Decisions of Local People to Participate in Community Tourism in the NorthWest of Vietnam. Journal of Contemporary Issues in Business and Government, 27(2), 226-232.

https://doi.org/10.47750/cibg.2021.27.02.028 
Van Dat, N., Nhi, D.T.A., \& Huy, D.T.N. (2021). Improving Tourism Entrepreneur's Competition during the COVID 19 Pandemic-A Case Study in Tourism Industry in Vietnam. Revista Geintec-gestao Inovacao E Tecnologias, 11(3), 112-126.

Hoa, N.T., \& Huy, D.T.N. (2021). Vietnam Tourism Services Development During and after Covid 19 Pandemic: Situation and Solutions. Revista Geintec-gestao Inovacao E Tecnologias, 11(3), 23-34.

Dat, P.M., Mau, N.D., Loan, B.T.T., \& Huy, D.T.N. (2020). Comparative China Corporate Governance Standards after Financial Crisis, Corporate Scandals and Manipulation. Journal of Security \& Sustainability Issues, 9(3), 931-941.

Van Tuan, P., Huy, D.T.N., \& Duy, P.K. (2021). Impacts of Competitor Selection Strategy on Firm Risk-Case in Vietnam Investment and Finance Industry. Revista Geintec-gestao Inovacao E Tecnologias, 11(3), 127-135.

Prayag, G. (2008). Image, Satisfaction and Loyalty-The Case of Cape Town. Anatolia: An International Journal of Tourism and Hospitality Research, 19(2), 205-224.

Tung, L.T. (2020). Tourism development in Vietnam: New strategy for a sustainable pathway. Geojournal of Tourism and Geosites, 31(3), 1174-1179.

https://doi.org/10.30892/GTG.31332-555

Uğur, N.G., \& Akb1yık, A. (2020). Impacts of COVID-19 on global tourism industry: A cross-regional comparison. Tourism Management Perspectives, 36. https://doi.org/10.1016/j.tmp.2020.100744

Vinh, N.Q., \& Long, N.L. (2013). The relationship among expectation, satisfaction and loyalty of international visitor to Hanoi, Vietnam. In Journal of Global Management, 5(1). http://dx.doi.org/10.1016/b978-008045046-9.09002-1

$\mathrm{Xu}$, J.B., \& Chan, S. (2016). A new nature-based tourism motivation model: Testing the moderating effects of the push motivation. Tourism Management Perspectives, 18, 107-110. https://doi.org/10.1016/j.tmp.2016.01.001

Mushtaq, R., Loan, F.A., \& Ali, M. (2017). Open access health and medicine journals - An informative study. Webology, 14(2), 90-100. 